\title{
Osteochondral Chip Fractures of the Palmar/Plantar Aspect of the Middle Phalanx in the Horse: 5 Cases (1991-1994)
}

\author{
F. Torre \\ Clinica Equina Bagnarola, Budrio, Bologna
}

\begin{abstract}
Summary
Osteochondral chip fractures of the middle phalanx in the horse are infrequent and usually affect the dorsal aspect of the proximal interphalangeal joint. Such fractures are even less frequently encountered in the palmar/plantar aspect of the middle phalanx, which generally cause lameness and call for surgical management. In this report five cases of osteochondral chip fractures of the middle phalanx in 5 horses (2 Standardbreds, 2 Show Jumpers and one Thoroughbred) are described: in two cases, the fragment originated from the palmar/plantar proximal border of the middle phalanx in the proximal interphalangeal joint; in one case from the proximal lateral palmar eminence; in two cases from the distal lateral palmar/plantar articular border in the distal interphalangeal joint. The surgical technique was more complex in regard to the fragments located in the distal interphalangeal joint. Removal of the fragments by arthrotomy is described - the operation involved removing part of the lateral cartilage of the distal phalanx. Of these 5 surgically treated cases, 4 returned successfully to the previous performance level, while one was lost for long term follow up.
\end{abstract}

keywords: $\quad$ chip fracture, middle phalanx, interphalangeal joint, surgical removal.

\begin{abstract}
Chip-Frakturen im palmar/plantaren Bereich des Kronbeins beim Pferd - 5 Fälle (1991-1994)
Chip-Frakturen des Kronbeins beim Pferd sind selten und betreffen gewöhnlich den Dorsalrand im Krongelenk. Selten treten solche Frakturen im palmaren/plantaren Bereich auf, sind dann aber mit deutlicher Lahmheit verbunden, und bedürfen einer chirurgischen Behandlung. Der Autor beschreibt 5 Fälle einer derartigen Fraktur (2 Traber, 2 Springpferde, 1 Vollblut). Bei 2 Pferden trat die Fraktur am proximalen Kronbeinrand intraartikulär auf, bei einem Pferd proximolateral. In 2 Fällen war der Distalrand im Bereich der Gelenkung mit Huf- und Strahlbein betroffen. Der bei diesen beiden Pferden angewandte Operationszugang war kompliziert und erforderte eine Teilresektion des Hufknorpels. Von den chirurgisch behandelten Pferden konnten 4 verfolgt werden, die alle einen unkomplizierten Heilungsverlauf zeigten und volle Funktion und Leistung erreichten. Ein Pferd konnte nicht nachuntersucht werden.
\end{abstract}

Schlüsselwörter: Chip-Fraktur, Kronbein, Krongelenk, Pferd

\section{Introduction}

Fractures of the middle phalanx of the horse have been grouped in two main categories: simple and comminuted (Colahan et al., 1980). Simple fractures generally concern the proximal interphalangeal joint, particularly the lateral palmar/plantar eminence. Comminuted fractures affect articular surfaces of the proximal and distal interphalangeal joint. Four types of fracture have been described: osteochondral chip fracture originating from the axial aspect of the palmar proximal border of the bone; uniaxial fracture of the medial or lateral palmar/plantar eminence; biaxial eminence fracture; comminuted fracture Watkins, 1996).

Osteochondral chip fractures of the middle phalanx are rare. They are caused by direct trauma or by an avulsion in correspondence with the ligamentous attachments (Stashak, 1987); according to some authors, such chip fractures chiefly concern Thoroughbreds, Hunters and Jumpers (Mcllwraith and Goodman, 1989). A case involving a fracture of the proximal palmar aspect of the middle phalanx was reported in a Warmblood hunter-jumper free of evident lameness, but poorly performing - lameness was noticeable only when moving in a circle Welch and Watkins, 1991).

An osteochondral chip fracture occurred in the distal dorsolateral aspect of the middle phalanx and the fragment was removed arthroscopically (Vail and Mcllwraith, 1992).

The proximal interphalangeal joint of the rear limbs is more frequently involved than the corresponding joint of the fore limbs (Colahan et al., 1980) and apparently there is a breed predisposition in western working horses (Mcllwraith and Goodman, 1989).

Management of osteochondral chip fractures of the dorsal aspect of the proximal interphalangeal joint can be either conservative or surgical, depending on the nature of symptoms and the horse's intended use (Stashak, 1987).

Osteochondral chip fractures of the palmar/plantar aspect, instead, generally require surgical management. This may prove challenging in regard to the anatomical peculiarity of the area (Modranski et al., 1982; Kainer, 1989; Welch and Watkins, 1991). As concerns the fragments originating from 
the proximal palmar/plantar border, the incision is performed on the palmar aspect of the proximal interphalangeal joint and extends to the subcutaneous fascia and the distal annular ligament. Following incision of the deep digital flexor tendon sheath, the interphalangeal and metacarpophalangeal joint is flexed to enable lateral retraction of the tendons. The superficial distal sesamoidean ligament and the palmar joint capsule are incised, thus revealing the palmar proximal border of the middle phalanx, wherein the fragment is identified and removed. An intraoperative radiograph verifies complete removal of the fragment.

Fractures of substantial portions off the palmar/plantar eminence can, instead, compromise the stability of the proximal interphalangeal joint with the possibility of subluxation. Management of the more serious fractures requires internal fixation and, more often, arthrodesis of the proximal interphalangeal joint by means of previously described methods (Martin et al., 1984; Steenhaut et al., 1985; Doran et al., 1987; Bukowiecki and Bramlage, 1989; Caron et al., 1990; Crabill et al., 1995). In regard to comminuted fractures not elected for internal fixation, casting or transfixation casting are sometimes employed (Doran et al., 1987; Bukowiecki and Bramlage, 1989).

Prognosis for the more serious fractures is guarded or poor. Surgical complications include infection, failure of fixation, laminitis of the contralateral limb, and navicular disease (Watkins, 1996).

The purpose of this study is to assess the surgical methods and the results of 5 cases of osteochondral chip fractures of the palmar/plantar aspect of the middle phalanx, in 3 cases involving the proximal interphalangeal joint, and in 2 cases the distal interphalangeal joint.

\section{Materials and Methods}

Among the cases of osteochondral chip fractures of 'the middle phalanx diagnosed at the Clinica Equina Bagnarola (Budrio, Bologna) between 1991 and 1994, cases were selected in which the fragment was located at the palmar/plantar aspect of the bone, while ruling out the (more numerous) cases in which the fragment was located dorsally, usually axially or slightly abaxially with respect to the proximal interphalangeal joint. Seven cases were selected. Of these, two were not subjected to surgical management according to owners' wishes: the first, in fact, was an older fracture at the time of presentation and degenerative joint disease of the proximal interphalangeal joint was already present, thus jeopardising the prognosis. The other case, instead, involved the distal interphalangeal joint of a 14 year old mare used as a pleasure horse, which the owners preferred to use for breeding purposes.

The 5 remaining cases were subjected to surgical management involving removal of the fragment. This group included 3 males, a gelding and a female, of which 2 were Standardbreds, 2 Show Jumpers and one Thoroughbred. The average age was 5.6 years, with a range between 2 and 9 .
In 2 cases the fragment involved a front limb and in 3 cases a pelvic limb (see table 1).

Tab. 1: data on age, sex, breed and limb involved of the 5 cases. Aufstellung über die Verteilung von Alter, Geschlecht, Rasse und betroffene Gliedmaße.

\begin{tabular}{|c|c|c|c|c|}
\hline Case no. & Age (years) & Sex & Breed & Limb \\
\hline 1 & 7 & M & STB & LF \\
\hline 2 & 7 & M & SJ & LH \\
\hline 3 & 9 & G & SJ & LH \\
\hline 4 & 3 & M & STB & LH \\
\hline 5 & 2 & F & TB & RF \\
\hline
\end{tabular}

M: Male; F: Female; G: Gelding; STB: Standardbred; SJ: Show Jumper; TB: Thoroughbred; LF: Left Front; LH: Left Hind; RF: Right Front.

The horses were operated in lateral recumbency with the affected limb up, when the fragment was located laterally (cases no. 1, 2 and 3) or axially (cases no. 4 and 5).

The surgical technique varied according to the location of the fragment. In two cases with fragments off the palmar or plantar proximal articular border, the approach previously described was used (Modransky et al., 1982; Welch and Watkins, 1991).

In one case of osteochondral chip fracture off the proximal lateral eminence of the middle phalanx, probably caused by avulsion (figure 1), the incision was made directly over the eminence. After dissecting the surrounding ligamentous attachments, the fragment was easily isolated and removed.

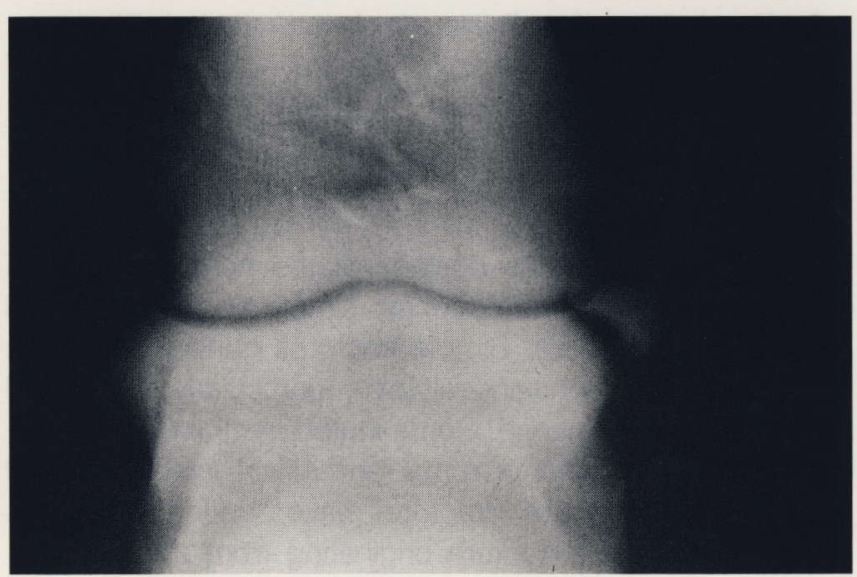

Fig. 1: Case no. 2. Osteochondral chip fracture of the lateral palmar eminence of the middle phalanx in a 7 year old Show Jumper.

Fall 3. Chip-Fraktur der lateralen Kronbeinlehne bei einem 7-jährigen Springpferd.

Two cases with an osteochondral chip fracture off the distal palmar articular border were managed with a more complex surgical technique. An "L"shaped incision was made over the proximal palmar border of the collateral cartilage of the distal phalanx on the affected side. Following blunt dissection of the subcutaneous tissue, the lateral cartilage of 
the distal phalanx was identified and, as it proved impossible to displace it sufficiently, a rectangular portion of it was removed, with the base slightly above its attachment on the lateral proximal part of the palmar/plantar process of the distal phalanx. The more palmar portion of the cartilage was preserved, as several veins pass that portion through appropriate foramina (Kainer, 1989). It was then possible to continue dissection, until the joint capsule of the distal interphalangeal joint could be incised. The joint had been previously distended by intra-articular injection of saline solution through the dorsal recess. The main vessels and nerves were accurately identified and isolated. The use of a suction apparatus proved to be beneficial once the joint was reached. The articular structures and the fragment were subsequently identified. In one case, the fragment was without any attachment, positioned in its fracture bed (Figures 2 and 3).

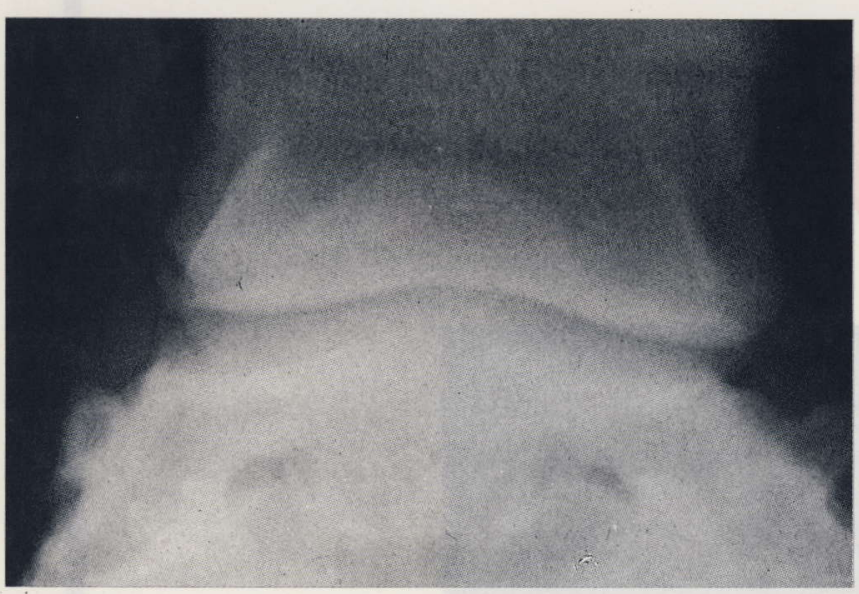

Fig. 2: Case no. 1. Osteochondral chip fracture off the latera distal palmar articular border of the middle phalanx in a 7 year old Standardbred.

Fall 2. Chip-Fraktur des laterodistalen Krongelenkrandes bei einem 7-jährigen Traber.

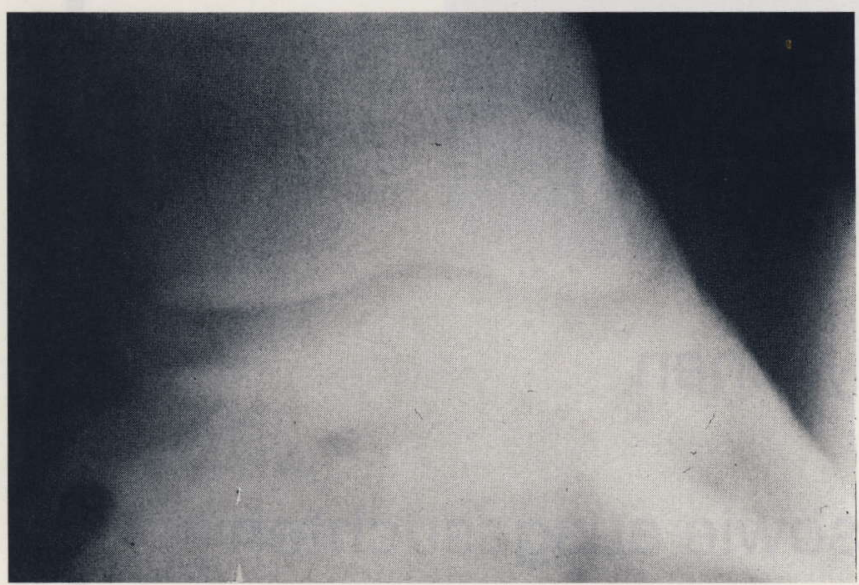

Fig. 3: Same case as Figure 2. The oblique view shows the fragment off the middle phalanx at the articulation with the distal phalanx and the navicular bone.

Derselbe Fall aus Abb. 2. Die Schrägprojektion zeigt das Kronbeinfragment im Bereich des Hufgelenks.

In the other case, the fragment which was larger had first to be freed from its attachments with the help of an elevator before it could be removed. In all the cases, the complete removal of the fragment was verified through intra-operative radiographic views (Figure 4). Following articular flushing, the articular capsule was closed with interrupted sutures using 0 -Polyglycolic acid. The same suture material and pattern was used for the subcutaneous tissue. Non reabsorbing material was used for interrupted suture of the skin.

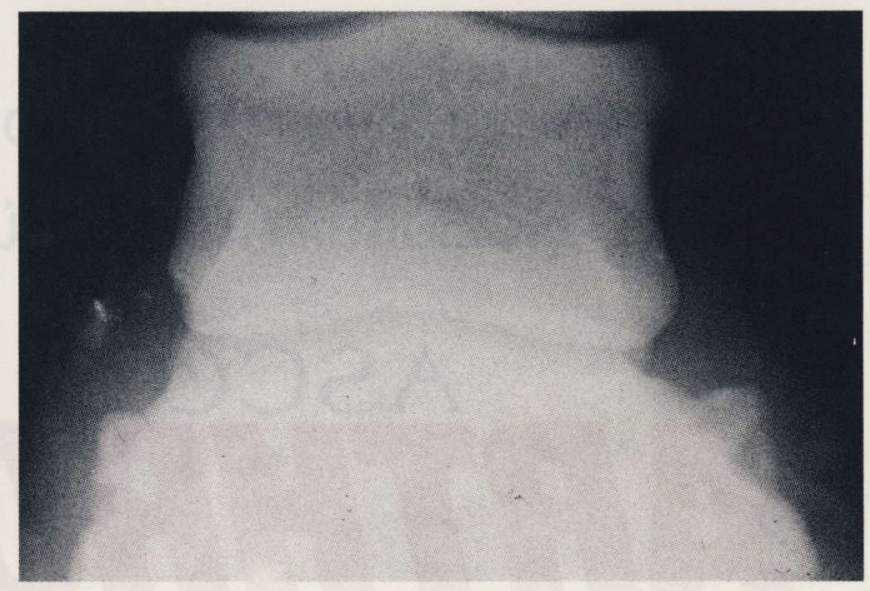

Fig. 4: Same case as Figure 2. Radiographic control after removal of the fragment.

Fall aus Abb. 2. Postoperative Kontrollaufnahme.

\section{Clinical cases and Outcome}

Cases are summarised in Table 1.

\section{Case no. 1}

7 year old male Standardbred, left front limb (Figures no. 2, 3 and 4).

The horse had an osteochondral chip fracture of the distal lateral palmar articular border with a lameness of acute onset. It went back into training 45 days after the operation and gradually returned to normal racing activity at its previous level. It ran up to the permissible age limit (i.e. 10 years) without any symptoms on the operated limb.

\section{Case no. 2}

7 year old male Show Jumper, left hind limb (Figure no. 1). The fracture involved the proximal lateral plantar eminence, causing lameness of the degree $2 / 5$. After a 2 months rest period, the horse resumed normal activity without any symptoms on the operated limb.

\section{Case no. 3}

9 year old gelding Show Jumper, left hind limb.

The fragment originated from the distal lateral plantar articular border and was associated with mild lameness. After the surgery, the horse was rested for 2 months and then gradually returned to work, with excellent performances.

\section{Case no. 4}

3 year old male Standardbred, left hind limb.

The osteochondral chip fracture was located at the proximal plantar articular border of the middle phalanx associa- 
ted with a mild lameness. The horse had never raced when the fracture occurred. It went back in training two months after the operation and started a racing career without untoward interruptions. The owner did not report any problems related to the operated limb.

\section{Case no. 5}

2 year old female Thoroughbred, right front limb (Figure no. 5). This filly was referred for surgery after a fragment from the proximal palmar articular border of the middle phalanx was identified as the cause of intermittent lameness. In view of its youth, after being operated, the filly was left on the pasture for a five months period. The owner reported good functional recovery and absence of lameness while the filly was in the paddock, although the radiographic examination carried out by the referring veterinarian revealed irregularities at the surgery site, and new bone formation in the region of the joint capsule. The filly was subsequently sold, it never raced and was lost for long term follow up.

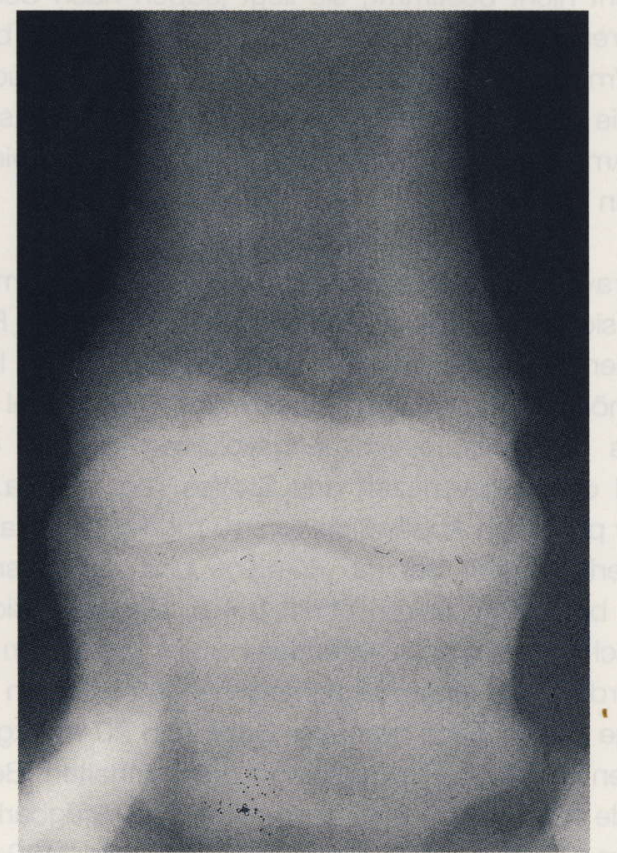

Fig. 5: Case no. 5. Fragment off the proximal palmar articular border of the middle phalanx in the proximal interphalangeal joint of a 2 year old Thoroughbred.

Chip-Fraktur im Bereich der Krohnbeinlehne bei einem 2-jährigen Rennpferd.

\section{Discussion}

Removal of osteochondral chip fractures of the palmar/plantar aspect of the middle phalanx is more complicate than dorsal fragments. Luckily the latter occur much more frequently. Moreover, the clinical signs of the fragments off the palmar/plantar aspect are more serious and conservative management does not offer acceptable results. Surgery is strongly encouraged if the horse is intended for an athletic career.
Fragments originating from the lateral or medial eminence, which are probably due to ligamentous avulsion, can be easily reached through an incision directly over the affected area, thus avoiding vessels and nerves, and cause the least amount of trauma to the ligamentous attachments as possible. Fragments located more axially with respect to the proximal palmar articular border, require a more complex approach and accurate radiographic monitoring.

The surgical management of fragments originating from the distal palmar/plantar articular border of the middle phalanx, is challenging. As cases no. 1 and 3 show, results can be good, even cosmetically, despite the fact that the technique is very invasive.

Arthroscopy could improve the management of such chip fractures. Arthroscopic management of lesions located in the dorsal aspect of the distal interphalangeal joint has been described and is recommended for the removal of fragments off the extensor process of the distal phalanx (Boening et al., 1988). The same portal was also used to remove a fragment from the dorsolateral corner of the distal articular border of the middle phalanx (Vail and Mcllwraith, 1992).

The arthroscopic access to the palmar/plantar proximal pouch of the same joint was experimentally described (Vacek et al., 1992) a short time after the surgical management through arthrotomy of the two cases presented here. This technique showed good visibility of structures within the palmaroproximal or plantaroproximal pouch of the distal interphalangeal joint. The use of arthroscopy for the removal of osteochondral fragments in this area of the distal interphalangeal joint should be developed in the near future, making the surgical technique simpler and possibly improving the outcome.

\section{References}

Boening, K.J., Von Saldern, F.C., Leendertse, I.P. and Rahlenbeck, F. (1988): Diagnostische und operative Arthroskopie am Hufgelenk des Pferdes. Pferdeheilkunde, 4, 155-160.

Bukowiecki, C.F. and Bramlage, L..R. . (1989): Treatment of comminuted middle phalangeal fracture in a horse by use of a broad dyna mic compression plate. J.Am.Vet.Med.Ass., 194, 1731-1734.

Caron, J.P., Fretz, B.B., Bailey, J.V. and Barber, S.M. (1990): Proximal interphalangeal arthrodesis in the horse: a retrospective study and a modified screw technique. Vet. Surg., 19, 196-202.

Colahan, P.T., Wheat, J.D. and Meagher, D.M. (1981): Treatment of middle phalangeal fractures in the horse. J.Am.Vet.Med.Ass., 178, 1182-1185.

Crabill, M.R., Watkins, J.P., Schneider, R.K. and Auer, J.A. (1995): Double plate fixation of comminuted middle phalangeal fractures in horses (1985-1993). J.Am.Vet.Med.Ass., 207 (11) 1458-1461.

Doran, R.E., White, N.A. and Allen, D. (1987): Use of bone plate for treatment of middle phalangeal fractures in horses: 7 cases. J.Am.Vet.Med.Ass., 191, 575-578.

Kainer, R.A. (1989): Clinical anatomy of the equine foot. Vet.Clin. of North Am.: Equine Pract., 5 (1) 1-27.

Martin, G.S., Mcllwraith, C.W. and Turner, A.S. (1984): Long-term results and complications of proximal interphalangeal arthrodesis in horses. J.Am.Vet.Med.Ass., 184, 1136-1140.

Mcllwraith, C.W. and Goodman, N.L. (1989): Fractures of the middle phalanx affecting the articulations of the proximal and/or distal in- 
terphalangeal joint. Vet.Clin.of North Am.: Equine Pract., 5 (1) 164-167.

Modransky, P.D., Grant, B.D., Rantanen, N.W. and Corey, D.G. (1982): Surgical treatment of a palmar midsagittal fracture of the proximal second phalanx in a horse. Vet. Surg., 11, 129-131.

Stashak, T.S. (1987): Fractures of the middle (second) phalanx. In: Stashak TS, ed.: Adam's Lameness in Horses. Philadelphia, 560-563.

Steenhaut, M., Verschooten, F. and De Moor, A. (1985): Arthrodesis of the pastern joint in the horse. Equine vet. J. 17 (1) 35-40.

Vacek, J.R., Welch, R.D. and Honnas C.M. (1992): Arthroscopic approach and intra-articular anatomy of the palmaroproximal or plantaroproximal aspect of distal interphalangeal joints. Vet. Surg., 21 (4) 257-260.

Vail, T.B. and Mcllwraith, C.W. (1992): Arthroscopic removal of an osteochondral fragment from the middle phalanx of a horse. Vet. Surg., 21 (4) 269-272.

Watkins, J.P. (1996): Fractures of the middle phalanx. In: Nixon A.J., ed.: Equine Fracture Repair , Philadelphia, 129-145.

Welch, R.D. and Watkins, J.P. (1991): Osteochondral fracture of the proximal palmar middle phalanx in a Thoroughbred. Equine Vet. J., 23 (1) $67-69$

\section{Dr Fabio Torre}

Clinica Equina Bagnarola

Via Armiggia, 25

I-40050 BAGNAROLA DI BUDRIO BO

Tel. and FAX 003951590583

Kurzreferat

\section{Amantadin und Pferdeinfluenza: Pharmakologie, Pharmakokinetik und neurologische Nebenwirkungen beim Pferd}

\author{
Amantadine and equine influenza: pharmacology, pharmaco- \\ kinetics and neurological effects in the horse
}

W.A. Rees, J.D. Harkins, W.E. Woods, R.A. Blouin, M. Lu, Clara Fenger, R.E. Holland, T.M. Chambers und T. Tobin (1997)

Equine Vet.J. 29, 104-110

Amantadin ist ein aliphatisches Amin mit antiviraler Wirkung gegen Influenza-A-Viren. Es wird in der Humanmedizin vor allem bei gefährdeten Personen zum Schutz gegen InfluenzaInfektionen eingesetzt. In vitro unterdrücken Amantadin und sein Derivat Rimantadin die Replikation der equinen Influenza2 -Viren in der Dosierung von weniger als $30 \mathrm{ng} / \mathrm{ml}$. Rimantadin weist ein breiteres antivirales Wirkungsspektrum auf als
Amantadin selbst. In der vorliegenden Studie wird untersucht, inwieweit sich Amantadin zur Prophylaxe und Therapie der equinen Influenza eignet. Die Autoren erforschen die antivirale Wirksamkeit, die Pharmakokinetik mit Bioverfügbarkeit und Verteilung, sowie die Nebenwirkungen des Stoffes beim Pferd.

Zu diesem Zweck erhalten 6 gesunde, erwachsene Vollblüter orale und intravenöse Amantadin-Gaben. Die Autoren nehmen den Pferden nach jeder Therapie Blut ab und bestimmen die Amantadinkonzentration. Sie gehen davon aus, daß ein Plasmaspiegel von $300 \mathrm{ng} / \mathrm{ml}$ Amantadin als therapeutisch wirksam betrachtet werden kann. Die intravenöse Applikation von $15 \mathrm{mg} / \mathrm{kg}$ Amantadin löst kurzfristig leichte ZNS-Symptome bei den Pferden aus, diese verschwinden jedoch spätestens nach 1 Stunde wieder. Die Dosierung von $15 \mathrm{mg} / \mathrm{kg}$ ist als maximal vertretbare Einzeldosis beim Pferd anzusehen. Sind jedoch wiederholte Injektionen nötig, sollte bei jeder Applikation nicht mehr als $10 \mathrm{mg} / \mathrm{kg}$ i.v. verabreicht werden. Die maximale sichere Dosis von Amantadin im Plasma wird in diesem Experiment nicht bestimmt, sie liegt jedoch nach Schätzung der Autoren bei über $2000 \mathrm{ng} / \mathrm{ml}$, eventuell sogar bei über $4000 \mathrm{ng} / \mathrm{ml}$. Allerdings warnen die Verfasser der Studie, daß Pferde, die zu neurologischen Ausfällen neigen, bereits bei geringen Amantadin-Konzentrationen fatale Nebenwirkungen entwickeln können.

Nach intravenöser Verabreichung von $10 \mathrm{mg} / \mathrm{kg}$ Amantadin gestaltet sich die Verteilung des Stoffes beim Pferd in Form eines offenen 2-Kompartimenten-Modells. Nach dieser Injektion wird die höchste Plasmakonzentration mit 4500 ng/ml gemessen. Das steady-state-Verteilungsvolumen beträgt ca. 4,9 $1 / \mathrm{kg}$, und die Halbwertszeit des Stoffes liegt bei ca. 1,8 h. Nach der peroralen Applikation von $10 \mathrm{mg} / \mathrm{kg}$ Amantadin liegt die Bioverfügbarkeit bei ca. $40-60 \%$ und die Plasmahalbwertszeit beträgt im Durchschnitt 3,4 h. Die orale Bioverfügbarkeit schwankt jedoch individuell stark unter den 6 Versuchspferden. Die pharmakokinetischen Messungen zeigen, daß einige Pferde nach peroraler Gabe von 20 mg/kg Amantadin einen effektiven Plasmaspiegel aufrechthalten. Bei anderen Pferde liegt jedoch eine so geringe Bioverfügbarkeit des Stoffes vor, daß sie die 6-fache orale Dosis $(120 \mathrm{mg} / \mathrm{kg}$ ) Amantadin benötigen, um einen wirksamen Blutspiegel des Stoffes zu erreichen. Ein 15-stündiger Futterentzug beeinflußt die Bioverfügbarkeit und Verteilung des Medikaments hingegen nicht.

Die Ergebnisse dieser Studie demonstrieren, daß eine einzige perorale Dosis Amantadin nicht ausreicht, um wirksame Blutspiegel beim Pferd zu erreichen. Die Plasmakonzentration des Stoffes liegt nach i.v.-Applikation eher im wirksamen Rahmen, die individuelle Schwelle der Pferde für neurologische Nebenwirkungen sollte jedoch nicht überschritten werden. Bei der akuten Gefahr einer Inflenza-Epidemie könnten die Pferde prophylaktisch alle 4 Stunden intravenöse Injektionen von jeweils $5 \mathrm{mg} / \mathrm{kg}$ Amantadin erhalten. Mit dieser Dosierung sollte es möglich sein, effektive Plasmakonzentrationen des antiviralen Wirkstoffes zu bekommen, ohne daß die Pferde neurologische Ausfallserscheinungen entwickeln. 